Vol. XXXVII - REVISTA DE HISTÓRIA - Ano XIX

\title{
ARTIG0S
}

\section{ENSAIO SÔBRE A HISTÓRIA DA MORAL E DA ARTE LÍRICA NA GRÉCIA (III).}

\author{
LINNEU DE CAMARGO SCHUTZER \\ Professor de História das Idéias do Departamento de \\ História da Faculdade de Filosofia, Ciências e Letras da \\ Universidade de São Paulo.
}

(Conclusão) .

\section{A POESIA ELEGIACA.}

\section{I. - Natureza e constituição da elegia.}

Ao tratar, nos capítulos precedentes $\left({ }^{*}\right)$, das origens e desenvolvimento da poesia lírica, assim como de seus diversos gêneros, distinguimos logo ao início, as composições monódias das composições corais, podendo a inspiração ser ou de caráter religioso, como nos cantos litúrgicos e nos hinos, em geral, ou de inspiração secular e pessoal, como se vê na elegia.

Êsses gêneros evoluiram, como sabemos, e a poesia lírica conservou o nome do qual proveio, a despeito dos novos instrumentos que vieram a servir em lugar da lira primitiva, sendo, em verdade, mais citarídica e aulédica do que pròpriamente lírica.

De outro lado, é bem provável que, em tempos posteriores, após o IV século, a composição métrica tenha prevalecido a ponto de dispensar inteiramente qualquer apôio instrumental.

Assim, no desenvolvimento da poesia lírica - indicação genérica que se conservou para tôda a poesia grega tratada no capítulo anterior - estava a elegia que, ao lado do nomo, é um de seus primeiros gêneros. 
A razão, porém, para tratar dos poetas elegíacos em capítulo à parte, está na importância maior que têm para o nosso estudo, em virtude do caráter sentencioso que lhes é próprio.

Essa distinção, com o maior relêvo que devemos dar à elegia, tem razão ainda na inspiração secular que a distingue do nomo litúrgico.

A primeira questão que, a propósito, deveria ser tratada, é a da origem da poesia elegíaca, procurando-se, na denominação que teve, as indicações possíveis sôbre a natureza de seu conteúdo que, sòmente a partir da idade alexandrina se reduziu ao de uma poesia triste e plangente.

Não era êsse, porém, o caráter necessário das primeiras composições elegíacas; e, se realmente prevaleceu sôbre as elegias de caráter marcial, como as de Tirteu, por exemplo, a razão se deve mais ao sentido de exortação, peculiar da elegia, e que se voltou progressivamente para a exortação moral, onde os gregos encontraram a primeira expressão espontânea de um sentimento de pezar pela condição humana.

A insistência, porém, com que se tem procurado na própria etimologia a indicação do conteúdo peculiar das composições elegíacas, aconselha deter-nos em alguns dos problemas levantados (81).

A tendência seria, naturalmente, a de aproximar o sentido etimológico do caráter mais comum à elegia; e, nessa direção se encontram as hipóteses que vêm em élegos a derivação e $\epsilon$ lége, expressão de lamento repetida como estribilho nas cerimônias de morte. Essa hipótese, por sua vez, supõe a elegia como um canto originàriamente litúrgico, acompanhado de música, e usado nos enterros. Dela se serviu Arquíloquo, em uma das mais antigas elegias que se conhecem, por ocasião da morte de um parente; e, ainda Eurípedes, muito mais tarde, a ela recorre para lamentar o desgraçado destino de Troia e de Heitor (Andrômaca, 103 e ss.). De outro lado, em élegos, sempre viram os antigos um sinônimo de threnos (82).

(81). - V. A. e M. Croiset, op. cit., II, pág. 91-92; De Falco e Coimbra, Os elegiacos gregos, pág. 29-30.

82) : - V. entre os gramáticos alexandrinos, especialmente Dídimo (século I a.c.), maís Horácio, Proclo. Hesíguio e escoliastas. Tentou-se também a aproximação de élegos ao verbo elecin - ter płedade; e ainda, a elegainen desvairar-se, também empregado como exaltar-se, inclusive em solenidades patrióticas e religlosas, nas quais, por vêzes, se usou a elegla. Algumas vêzes se indica por elegia o canto; e, outras, simplesmente a música que servla para a lamentação. 
Sendo a poesia elegíaca um canto áulico, supõe-se, de outro lado, provir a sua indicação de raízes armênias (83), das quais élegos seria a transcrição, para o grego, do próprio nome pelo qual a "cana" era conhecida entre os frígios, que dela criaram a flauta, a seguir transportada para a Grécia.

Esta outra etimologia - que não exclui a primeira - tem o mérito de distinguir o threno citarídico, existente desde a Ilíada, do threnos elegíaco, sòmente aulédico, como se vê na alusão que dêle se encontra em Eurípedes (84).

Assim, sem que se possa saber ao certo qual a escolher, devem elas ser aproximadas para ver-se na elegia "um canto aulédico de luto" (85), isto é, uma ária aulédica de lamentação.

De élegos provém elegeion - que diz respeito à métrica - usado em particular para o dístico elegíaco; e, ainda, no plural, elegeia - relativamente à ode - e que indica o poema constituido pelos vários dísticos, conservada a métrica usual do élegos.

Esta métrica (86), com o retôrno repetido dos tempos vazios que se seguem regularmente de um para outro dístico - como pausas em cada uma das metades do segundo verso - , dá à elegia o caráter de repetição monótona que resulta da obrigatoriedade da censura depois do quinto meio pé; e, os tempos silenciosos servem ao caráter plangente do canto usado como expressão de tristeza nas ocasiões de morte e enterramento.

Entretanto, o recurso métrico que se poderia supor responsável pelo uso da elegia como ode de lamentação, serviu igualmente para as odes marciais de exortação - como as de Tirteu - e para a poesia erótica que se seguiu, antes de se tornar a elegia a poesia pròpriamente sentenciosa.

Não devemos, pois, associar necessàriamente a métrica da elegia ao conteúdo dos primitivos cantós plangentes - que tem servido, inclusive, para as investigações etimológicas - nem à poesia gnômica, que representa um último estágio de evolução e consolidação do caráter sentencioso e triste pelo qual veio a ser conhecido.

Em verdade, o que se deve ver nas pausas repetidas, que seriam impróprias à narração épica e que cortam a poesia em unidades separadas, é apenas a unidade de expressão própria à cada unidade métrica, e às quais correspondem exortações breves.

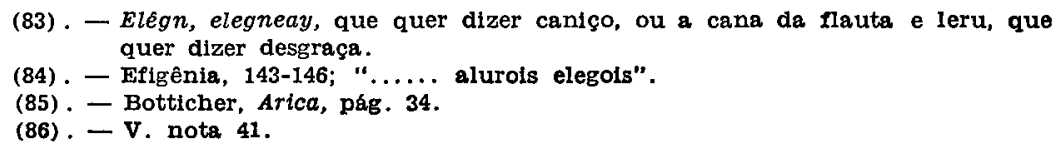
quer dizer desgraça.

(84). - Efigênia, 143-146; "..... alurols elegols".

(85) , - Botticher, Arica, pág. 34.

(86). - V. note 41 . 
Assim, se realmente a elegia veio a ser uma poesia sentenciosa e moralizante, é por que a moral, antes de tornar-se discursiva para a razão que nela iria procurar a demonstração de conceitos racionais, viveu nos limites de exortações proverbiais que eram apelos para a meditação, e para a virtude.

Essa razão se encontra claramente em muitos dos poemas elegíacos que trazem o título de Exortações - hypothechai - do qual, diz Croiset: "ce titre en dit à merveille la vraie nature".

Ao gnothi sauton que, na idade socrática, virá indicar uma nova direção para a moral - a procura de um conhecimento do Homem e de uma sabedoria que o levará a virtude - vemos antece-

der as hypothechai eis auton de Solon, poemas que já em seus títulos indicam a verdadeira natureza da elegia, no caso, de exortação à virtude, ora dirigida, em geral, aos que a ouviam, ora constituindo um apêlo à meditação própria e ao conhecimento da moral .

Dentro da variedade de seu conteúdo, por vêzes marcial, exortando os espartanos a manterem seu domínio sôbre os messênios, como em Tirteu, ou erótico, exortando aos prazeres da vida, como em Mimnermo (87), ou ainda pròpriamente gnômico, é sempre o caráter de exortação que constitui o principal motivo comum presente na elegia.

Assim, não nos parece razoável procurar-se na elegia um canto sempre plangente, e, menos ainda em razão apenas da estrutura métrica que lhe é peculiar.

Se, de um lado, é certo que os tempos vazios do pentâmetro serviam melhor para a expressão de lamento que se tornou o motivo principal da elegia sentenciosa, de outro lado é evidente que não se deve procurar no pentâmetro a razão de uma atitude moral, e menos do pessimismo que nele encontrou maiores recursos de expressão.

Sem ser elegíaca, a poesia didática de Hesíodo era igualmente moralizante, e seu pessimismo não era menor; e, na verdade, "il y a des élégies graves, d'autres moqueuses ou légères, d'autres doucement philosophiques. Ce qui domine pourtant, c'est le sérieux pratique et le goût de moraliser: il y a là une faculté nouvelle de l'ésprit grec qui grandit et qui crée une forme d'art appropriée" ... "Aussi la poésie élégiaque est volontiers sentencieuse, ou, comme disaient les Grecs, gnomique" ... "Elle est alors comme une autre forme de poésie didactique appliquée spécialment à la morale" (88).

Sôbre a evolução da poesia elegíaca, as imprecisões não são menores, incluindo-se, por vêzes, dentre seus primeiros cultores os auletas que se consagraram ao nomo.

\footnotetext{
(87) . - A propósito, vide Horácio (Epistolas, 1. I, 6) "Si Mimnermus uti censet. sine amore focisque Nil est jucundum, vivas in amore jocisque".

(88) . - M. e A. Croiset, op. cit., pág. 95-96.
} 
Esta tradição vem de Plutarco que (De Musica, c. 4, c. 3, c. 9, c. 8) escreve: ... "Clonas, o primeiro a compor nomos para a flauta e cantigas em honra dos deuses, com o nome de prosódia, compôs também poesias, umas elegíacas, outras épicas" ... “as árias que se tocavam na flauta eram a apotete, as elegíacas" ... "pois nos primeiros tempos os músicos se acompanhavam dêste instrumento, cantando elegias" ... "houve também um Sacadas de Argos, que compôs poesias líricas e elegias, que pôs em música" ...

A razão para Plutarco, seguindo tradição que encontrou, julgar os compositores auletas os criadores igualmente da elegia, estava no uso comum de um mesmo instrumento que, como vimos, tem seu nome associado à elegia .

Entretanto, a distinção que veio a prevalecer entre a elegia e o nomo aulédico já não consentiria ver-se em Clonas o primeiro poeta elegíaco nem em Sacadas o seu continuador.

Essa distinção não poderia estar no uso instrumental comum a um e outro gênero, como a diversos outros próprios do lirismo; e, sòmente a inspiração religiosa do nomo, à qual se opõe a inspiração secular da elegia, constituia a razão para se separarem de Clonas e dos.poetas religiosos de seu tempo, os primeiros poetas elegíacos de inspiração pessoal e independente que, servindo-se do rítmo elegíaco, por êle externavam sua tristeza e suas aspirações ao prazer.

Nessa separação, mais de conteúdo, como vemos, estavam as circunstâncias próprias a cada gênero; o nomo junto ao templo, e a elegia nas solenidades leigas da vida pública e nos banquetes em que cantaram os poetas elegíacos.

Se, pois, existiu primitivamente o nomo elegíaco, como dá a crer uma composição de Calino, em dísticos elegíacos em honra de Zeus, é preciso distinguí-lo da elegia não religiosa, que é o que verdadeiramente veio a constituir o critério para a sua separação. "On saisit là, ce semble - diz Croiset - le passage du nome élégiaque à l'élégie proprement dite", ao que, desde logo, devemos acrescentar, também a passagem da consciência moral religiosa, para a moral pròpriamente.

Essa separação, porém, só se daria progressivamente, e durante algum tempo vemos existirem elegias religiosas e seculares, dependendo apenas da ocasião a que eram destinadas.

Já assinalamos o caráter sentencioso pelo qual a elegia veio a ser conhecida, apesar de a poesia gnômica constituir apenas um de seus gêneros.

Esta evolução no sentido moralizante que veio a prevalecer, é paralela ao progressivo distanciamento da epopéia e à construção da prosa, num período em que as múltiplas tradições do povo grego de- 
veriam consolidar-se num patrimônio comum, no qual haveria ainda de ter lugar a cultura espúria recebida das colônias asiáticas.

A unidade nacional da narração épica já não comportava as novidades que iam separando as civilizações dórica, jônia e eólica, igualmente dissemelhantes do passado heróico da Ilíada e da Odisséia .

Entretanto, eram ainda essas novidades - irradiadas de suas diversas origens para todo o território grego - que provocavam um novo sentimento da história, no qual, sem se perder inteiramente o passado, a êle se associavam as novas conquịstas da civilização grega.

Do século VII ao século V assistimos, pois, a êste trabalho de consolidação da cultura grega - a que estão presentes os sete sábios - e que nos leva à prosa dos historiadores e naturalistas, vendo-se em Heródoto o duplo propósito de salvar o passado e de assegurar a importância do presente: "Herodotos of Halicarnassus presents the results of his researches in the following work, with the twofold object of saving the past of mankind from oblition and ensuring that the extraordinary achievements of the Hellenic and the Oriental worlds shall enjoy their just renonn - particularly the transactions which brought them into conflict with one another" (89).

Era, pois, natural que as vicissitudes porque passaram as civilizações helênicas encontrassem, antes da prosa de Esopo e da narração histórica do século V, uma primeira expressão das novas idéias ainda nos moldes tradicionais da arte lírica a que estavam habituados.

Essa circunstância deve ser acentuada no desenvolvimento da elegia, desde o primitivo nomo aulédico em dísticos e'egíacos, até sua consagração como poesia gnômica; pois "comme elle aspire à gouverner les âmes, elle réfléchit sur le bien et sur le mal, sur le but de la vie, sur la destinée, et elle en donne des leçons, qu'elle enferme dans des formules brèves et profondes. Ȧ la fin surtout de cette période que se extende de Calinos a Theognis - elle fait de parti pris ce qu'elle avait fait d'abord par rencontre et d'instinct. Elle tend peu à peu à n'être plus, dans Phocylide par exemple, que gnomique. Elle est alors comme une autre forme de poésie didactique appliquée spécialement à la morale" (90).

De outro lado, é em Esparta que as novas idéias e a nova arte se consolidam, para de lá se irradiarem pelo território grego.

A amálgama de povos, dialetos e ideologias presentes na arte grega, encontrará assim sua unidade em Esparta, com a trađição ci-. tarídica de Terpandro e aulédica de Clonas, vindo o dialeto dórico a tomar o lugar do dialeto jônio que antes prevalecera, em geral, na

(89) . - Arnold Toynbee, Greck Historical Thought, pág. 3.

(90) . - A. e M. Croiset, op, cit., II, pág. 96. 
composição da elegia, a ponto de se tornar o dialeto próprio da poesia coral, mesmo entre os autores trágicos. "C'est Sparte, à cet âge reculé, qui est le centre musical de la Grèce. C'est là que les traditions particulières se rencontrent, que les idées s'echangent, que l'art nouveau se constitue et se définit" ... "grâce à la primauté de Sparte, ces traditions précédement isolées se rapprochent; elles prennent conscience d'elles mêmes; elles se complètent et se corrigent réciproquement; et peu à peu l'art lyrique va se dégager de ce qui n'avait guère été encore qu'un heureux instinct" (91).

Apesar da proximidade de estilo que nos permite ver ainda na elegia uma herança da epopéia - com a presença, inclusive, de epítetos homéricos que se conservam em tôda a poesia grega - outras distinções existem que separam a poesia heróica da poesia elegíaca, também com respeito à progressiva dominação do dialeto dórico.

Em verdade, aparecem na elegia expressões posteriores a Homero, desconhecidas até então da linguagem consagrada pela poesia épica, e nas quais é possível perceber a maior liberdade de composição que a separa da tradição eólica, arcáica, tornando a elegia uma poesia contemporânea, em que se revelam com espontaneidade, os costumes jônicos próprios ao dialeto ático de Solon, ou as novidades da cultura espartana, em caldeamento, na predominância do dialeto dórico, mais vivo e atual.

Ao lado da evolução dialetal, vemos mais na composição da elegia uma estrutura lógica diversa da epopéia. Sendo o seu propósito o da exortação, era natural procurar, com o recurso do dístico, o caráter enérgico que não é essencial à narração épica; e, ainda que não se encontre na elegia um pensamento discursivo em que as idéias se demonstrem à maneira de conclusões necessárias, o resultado alcançado no domínio da sensibilidade moral, que é igualmente estética, não é menor, podendo-se entrever, na seqüência dos versos, uma "dialética latente" - como diz Croiset - que inspira tôda a poesia e lhe assegura uma unidade que se desenvolve semelhantemente a um progresso lógico.

A progressão dialética nas elegias constituidas por vários dísticos resulta da dupla amputação do pentâmetro, que permite a oposição imediata de idéias. Em geral, essa oposição é repetida nos versos seguintes - por meio de novas imagens poéticas que encontram no paralelismo dos versos a intensidade dramática conveniente ao convencimento da conclusão para a qual se pro segue, - ou, desde logo, concluida no verso imediato, como se resultante da oposição antes construída.

(91). - A. Croiset, La poésie de Pindare et les lois au lyrisme grec, pág. 27. V. Plutarco, De Musica, XII. 
Do ponto de vista lógico, há pois um progresso da razão que aproxima a elegia da construção dialética na qual irá mais tarde desenvolver-se o pensamento discursivo.

Se não existe ainda a maiêutica dos conceitos voltada só para a razão, entretanto, a maneira de convencer pela oposição de imagens e idéias, constitui um primeiro ensáio de oposição dialética que dá à elegia o sentido de uma maiêutica do espírito voltado para os sentimentos espontaneamente originados da experiência moral.

Dêsse processo não estava ausente a experiência estética que se associava à lógica das oposições construidas pela imaginação livre dos modelos arcáicos; e a harmonia dos dísticos breves dava à elegia maior clareza e sobriedade. "Dans la poésie grecque, l'imagination et le sens de la beauté plastique ne sauraient jamais perdre tous leurs droits; mais la sévère raison a certainement grandi dans l'intervalle, ei s'est fait une plus large place; les comparaisons, moins fréquentes que chez Homère, sont plus précises et plus serrées" (92).

Assim é que a "dialética latente" desenvolvida pela elegia, em uma linguagem simples e clara, dispensando o acompanhamento musical (93) em que encontrara a estrutura métrica que sobreviveu independentemente do canto, irá coincidir com o desenvolvimento da prosa que com igual propósito moralizante a acompanha já no século VI, no qual, provàvelmente, existiram, também, escritos elegíacos dirigidos apenas à leitura, como parece provar o aparecimento, nesse tempo, do epigrama.

Voltada para a exortação e constituida de dísticos breves que procuram o convencimento pela oposição de idéias ou simples comparação de imagens, não haveria, na elegia, o lugar, nem a oportunidade, que a epopéia dispensou aos mitos consolidados pela poesia homérica .

"Nos poetas posteriores a Homero - diz Jaeger - vemos sempre a progressiva concentração em elaborar o conteúdo racional da poesia, quer pela expressão de suas próprias crenças pessoais ou pelo estabelecimento e exposição de normas gerais com as quais deveriam concordar os cidadãos da comunidade. A maioria da poesia

\footnotetext{
(92). - A. e M. Croiset, op. cit., II, pág. 98.

(93). - As incertezas relativas ao tempo em que a poesia elegiaca se dissociou do canto aulédico - desde Solon e Teognis, segundo Ateneu, ou sòmente mais tarde, segunóo as alusóes do próprlo Teognis aue levam a crer na existência da elegia aulédica ainda ao século $\mathrm{v}$ - năo permitem dizer ds uma origem elegíaca da prosa, como se da poesia cantada se passasse para a recitaçăo, e dela para a prosa sem métrica. Entretanto, é certo que a prosa existente já ao século VI, ao lado da elegia, e que como ela se inspirava de um propósito didático - em Esopo - encontrara na independência da estrutura métrica da elegia e na simplicidade de sua linguagem clara e sábla a oportuntdade para o desenvolvimento de uma argumentação discursiva mais próxima da razáo com que a moral virá a ser tratada nos séculos posteriores.
} 
posterior a Homero realmente proveio da epopéia; mas, tendo-se dela tornado independente, a tradição mítica, - na qual estava todo o conteúdo da epopéia - seria, ou inteiramente abandonada como em Tirteu, Calino, Arquíloquo, Simônides, Solon, Teognis, e usualmente entre os poetas líricos e Mimnermo - ou introduzida apenas exteriormente" ... "como exemplos míticos para explicar as idéias não míticas e puramente conceituais do poeta" (94) .

Se, porém, algumas vêzes ainda se mantém a alusão ao mito, especialmente em se tratando de elegias religiosas, já não é mais a sua narração que sobrevive, mas apenas o conteúdo no qual se possa encontrar uma aproximação entre a consciência moral e religiosa.

De outro lado, é no desaparecimento do recurso constante às construções mitológicas comuns à epopéia que encontramos mais do que a separação entre períodos e gêneros diversos da poesia, a independência da consciência moral que se vai libertando da herança religiosa do passado na própria medida em que se volta para uma meditação espontânea sôbre a experiência humana. "Viewed in this light, the gnomic poets mark a transition from Homer and Hesiod to the dramatists and moralists of Attica. The ethical precepts inherent in the epos received from them a more direct and proverbial treatment; while they in turn prepared for the sophists, the orators and Socrates" (95).

\section{II. - Os primeiros elegíacos: Da exortação guerreira à Eunomia.}

Dissemos que a poesia elegíaca veio a ser conhecida pelo caráter sentencioso e moralizante próprio ao seu último estágio de poesia gnômica, sem que, entretanto, constituisse êle o motivo necessário da elegia.

A propósito, lembramos as composições marciais de Tirteu e os versos eróticos de Mimnermo, nos quais a exortação se dirigia ou para as virtudes guerreiras dos espartanos ou para os prazeres da vida mais tarde ensinados pelos hedonistas e epicureus.

Assim, retomando a diversidade dos motivos presentes nas composições elegíacas, devemos mais lembrar, desde logo, que nem sempre é possível separar, pelo conteúdo principal de sua poesia, os compositores que, além dos gnomos elegíacos, igualmente se dedicaram à poesia pessoal e composições eróticas, atendendo, como já vimos, às oportunidades diversas .

De outro lado, a poesia gnômica - que especialmente deve interessar ao estudo da moral helênica - não era apenas elegíaca. Alguns outros poetas líricos, autores de composições jâmbicas, devem igualmente incluir-se na relação dos poetas gnômicos, tais como

(94). - Op. cit., vol. I, pág. 242.

(95). - J. A. Symonds, Studies of the Greek poets, vol. I, pág. 221. 
Simônides de Amorgos, por exemplo, e também Arquíloquo, mais jâmbico do que elegíaco. "In fact — diz Symonds - the gnomic poets represent a period of Greek literature during which the old and simple forms of narrative poetry were giving way to lyrical composition on the one hand and to meditative writing on the other; when the epical impulse had become extinct, and when the Greeks were beginning to think definitely" (96).

A razão, entretanto, para manter-se a separação dos poetas gnômicos nos gêneros líricos em que mais se consagraram, está na íntima associação que sempre existiu na arte grega, em geral, entre os recursos de expressão sensível e o conteúdo ideológico a que serviu com a peculiaridade de experiências estéticas próprias à diversidade de inspiração.

Tendo a cultura grega procurado igualmente na arte uma pedagogia, é aconselhável manter-se a unidade que existia para os gregos entre a arte e a moral, como uma só experiência que não poderia ser inteiramènte conhecida em apenas um de seus elementos.

Se, pois, à moral interessa especialmente o conteúdo da poesia gnômica desenvolvida em vários gêneros do lirismo, de outro lado é preciso ter sempre presente o resultado estético de cada um daqueles gêneros, para melhor se compreenderem as idades da consciência moral, desde a sua primeira expressão religiosa, até ao racionalismo conceitualista em que a virtude se tornaria a ciência do bem.

Nessa evolução, vimos a importância que teve, para a exortação à virtude, a estrutura métrica da elegia e sua composição próxima à dialética; e, sabemos também que da epopéia para a elegia a consciência moral deveria passar da idade religiosa da moral para a idade do sentimento moral.

Conservando, pois, a distinção entre os gêneros líricos, devemos iniciar pelos primeiros de seus poetas, ainda que não voltado para a moral sentenciosa da poesia gnômica e tendo por motivo as vicissitudes históricas do momento.

Assim, o conteúdo marcial próprio às composições de Calino e Tirteu, em geral constituidas de exortacões patrióticas consaoradas às virtudes guerreiras, teve a sua oportunidade, quanto a Calino, na defesa de Efeso contra os cimerianos (97) e, em Tirteu, na dominação imposta pelos dóricos aos messênios.

São, pois, composições que celebram as virtudes guerreiras semelhante ao ideal aristocrático da moral heróica da epopéia; e, se de um lado a presença do mesmo motivo ós aproxima da epopéia, de outro, a herança do gênero épico haveria de pesar sôbre os primeiros

(96). - Op. cit., vol. I, pág. 221.

(97). - 0 que se pode concluir de dois de seus fragmentos: " $\mathrm{F}$ tende pledate do esmirneanos", e "e agora vem covardemente a hoste dos cimerianos". 
poetas elegíacos, "pois Calino, como Tirteu, imitou o estilo de Homero, associando à forma épica o novo sentido da comunidade própria à cidade-estado" (98) .

De Calino, pouco se poderá dizer a partir dos raros textos conservados, incompletamente, por Estobeu - em especial - Estrabão, Pausânias e Ateneu, e contra os quais, aliás, se levantam dúvidas, tendo-se mesmo pensado não se tratar de um personagem real.

A crer, porém, na sua autenticidade, vemos em Calino reminiscências homéricas que se cruzam no dialeto jônio de que se serv u, em uma composição que, sendo elegíaca, é, porém, de natureza épica; e, imitando a Homero, realmente alcançou um estilo enérgico, com movimento de imagens em oposição, como era próprio da exortação elegíaca.

De seus poemas, o único que, pela sua extensão pode dar-nos uma idéia da elegia guerreira primitiva, é um encômio à coragem, conservado por Estobeu (99).

(98). - W. Jaeger, op. cit., vol. I, pág. 93.

(99) . - "Por quanto tempo sereis indolentes? Quando,

havereis vós, oh! jovens, de revelar um coraçăo intrépido?

Nâo tendes vergonha pela indolência com

que os vedes - os inimigos - permanecerem entre vós?

Credes estar em paz quando todo o país está

coberto pela guerra?

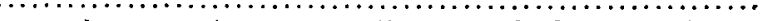

que cada um, mais uma vez atire o seu dardo, enquanto morre.

Pois, é glória e honra para o homem

combater o inimigo para a pátria, para

as crianças e para a mulher virgem com que se

casou; e a morte somente virá quando o

Destino assim ordená-1a. Porém, logo que a guerra

é existente, cada um para ela deve

seguir, levantando a lança e o escudo

sôbre o coração valente; pois de nenhum

modo pode um homem livrar-se da

morte, senão provier de linhagem

imortal. Muitas vêzes pode acontecer

que, voltando salvo das lutas em tatalha,

e de cair pela lança, na sua casa sôbre

êle venha a perdição da morte; mas

êste não é nem caro ao povo nem por

êle deplorado; enquanto se de outra

sorte acontecesse, êle seria deplorado por

pequenos e grandes. Quando morre um

her6i todo o povo lamenta a sua morte,

e enquanto vive a êle se dão honras como

a um semideus; pois aos seus próprios

olhos êle se eleva como uma tôrre,

vendo que a sós realizou o dever de

muitos".

(Texto editado por J. M. Edmonds, "Elegy and Iambus". Perderam-se dêste texto - diz Croiset, alguns versos consagrados à descrição do país em perigo, constituindo a sua primeira parte o início do poema. Os demais textos incompletamente conservados, săo a Zeus (dois versos) e - que alude aos cimerianos (um verso). 
A inspiração épica dêste poema é indiscutivel.

Nêle, é ainda a moral heróica dos tempos homéricos que se revela em versos que lembram a imortalidade da glória procurada pelo herois da Ilíada; "mas êste não é caro ao seu povo nem por êle deplorado; enquanto se de outra sorte acontecesse êle seria deplorado por pequenos e grandes; quando morre um heroi, todo o povo lamenta a sua morte".

A inspiração homérica existe ainda nestes versos de Calino com relação a dois outros temas que tiveram especial importância para a moral heróica: a irrevogabilidade do Destino e a glória pela realização do dever, que é o apêlo à ação heróica .

A separação entre os mortais e imortais é clara em Calino: "pois de nenhum modo pode o homem livrar-se da morte, senão provier de linhagem imortal". Nestes versos, vemos sobreviver a distinção homérica entre a ordem humana $\mathrm{e}$ a ordem divina de descendência, sendo a morte irrevogável para a primeira: "e a morte sòmente virá quando o Destino assim ordená-la”.

De outro lado, tôda a exortação contida nêste poema é um apêlo ao dever, no qual está a glória e a honra: "pois é glória e honra para o homem combater ... para a pátria, para as crianças" e, para a posteridade.

O herói, se alcançado pela lança inimiga, será deplorado por todo o seu povo; e, se a ela sobreviver, se elevará como uma tôrre por haver realizado o dever que é o seu destino, e o dever de muitos. Essa será a sua glória, aos seus próprios olhos, e na memória da posteridade, em que sobrevive a lembrança dos heróis homéricos.

Ainda com relação ao poema de Calino - e, nessa circunstância está algo de novo na tradição jônia - o apêlo que nele se contém é dirigido a todos os cidadãos, e não apenas aos guerreiros. "A coragem perante o inimigo, até à entrega da vida pela pátria, é uma exigência que se impõe como lei aos cidadãos e para o cumprimento da qual se reclamam pesados sacrifícios" (100).

Sem pretender dar a essa circunstância todo o alcance que nela se tem procurado, é certo, porém, que a maneira pela qual Calino estende a todo o cidadão o dever antes restrito apenas aos guerreiros, consente pensar-se na universalização do dever, que será uma das conquistas do humanismo grego, na medida em que a consciência moral se liberta das tradições da epopéia e das separações de classe.

(100). - W. Jaeger, op. cit., vol. I, pág. 105. 
Assim é que as elegias guerreiras virão pertencer a tôda a Grécia. "Das provações da guerra, e das lutas de partido de um mundo não heróico, um novo heroismo surgiu como última inspiração de uma verdadeira poesia. Esta nova poesia cantada nos momentos mais graves de crise da polis, alcançou, por essa razão, um lugar seguro ao lado do mundo ideal de Homero" (101) .

Seu maior representante será Tirteu, e não é sem razão que a sua poesia guerreira - de especial importância para a vida de Esparta - se divulgou para as demais regiões, como para Atenas (102), onde veio a ser ensinada aos jovens, ao tempo de Sócrates, sendo ainda lembrada por Licurgo na evocação da idéia de coragem.

Também, sôbre Tirteu, divergem as tradições conservadas pelos antigos; e as incertezas quanto à sua origem (103) já levaram a pensar-se num personagem imaginário, em nome de quem vieram agrupar-se muitas das elegias guerreiras que existiram, de autores anônimos, nas diversas regiões da Grécia (104).

Seu nome se tornou lendário; porém, parece ser incontrovertida a sua existência histórica, em Esparta, na segunda metade do século VII, assim como de sua poesia (105).

(101). - Ibidem, pág. 95-96.

(102). - Platão (Leis, IX, 858) e Xenofonte (Mem. I, 6, 14) aludem à poesia sentenciosa "dando conselhos sôbre a conduta na viđa" e que os críticos (Girard, l'Education Athénienne, pág. 148) acreditam ser as de Tirteu. A alusão, porém, é genérica e parece-nos que năo deve ser restrita à elegia guerreira.

(103). - Diz-se que, durante a segunda guerra dos messênios, os lacedemônios ouviram do oráculo de Delfos a ordem para pedirem um comandante ass atenienses que, por ironia, lhes enviaram Tirteu, que era manco, e que disputando a coragem dos lacedemônios, com suas elegias guerreiras, levou-os à vitórla. Sua origem ateniense coincidiria, assim, com a origem jônia da elegia, e, por manco, pretenderia a lenda indicar a amputação do pentâmetro. A esta tradição, conservada por Estrabão, opóe-se a que se contem na Suida, que o considera natural de Mileto, igualmente origem do canto aulédico. De qualquer maneira tornou-se êle um cidadáo de Esparta, tendo dela recebido o direito de cidadão: "Lembrarel primeiramente a Tirteu, ateniense por nascimento, mas também um cidadáo espartano, que era dentre todos os homens, o mais ardente pela guerra" (Leis, I, 629). Ao lado de sua provável origem ateniense ou milesiana, é provável que Tirteu seja realmente natural de Esparta - ou, pelo menos, dórico - como já se pensou a partir de seus fragmentos II e III, e pelos dorismos que se encontram em sua obra.

(104). - Supōe Wilamowitz que, na coletânea dos poemas de Tirteu houve uma reelaboração que alcançou até ao século IV a.C.

(105) . - V. Ariśtóteles, Política, V, 7,35 ... "ou ainda - ocorrem revoluçóes quando alguns sáo muito pobres e outros muito ricos, estado da sociedade na maioria das vêzes resultante de guerra, como na Lacedemônia, nos dias da guerra messênia; isto é provado pelo poema de Tirteu, intitulado Eunômia; pois êle diz de alguns cidadâos que, arruinados pela guerra, queriam uma redistribuiçấo da terra". 
Sua real participação na vida militar de Esparta parece improvável, devendo-se entender de outro modo as palavras com que o próprio poeta - segundo Estrabão - teria dito "haver conduzido a guerra".

De qualquer modo, porém, os acontecimentos da vida de Esparta se encontram nos versos de Tirteu, especialmente a êles consagrados, e que se inspiram de uma atitude peculiar às tradições dóricas, a ponto de constituirem a demonstração convincente de uma vontade política que se extendeu para além da existência histórica do estado espartano, e de se elevarem a normas de ação e pensamento nem sempre limitadas às exigências circunstanciais da guerra. "Tirteu não é um gênio poético individual, mas sim a voz de um povo que proclama a crença de todo cidadão consciente e responsável" (106), a "voz pública da pátria" como diz Demóstenes (107).

Nas composições de Tirteu encontramos uma novidade com relação às de Calino: além das exortações guerreiras, pròpriamente, existem também, dentre suas elegias, exortações às virtudes da vida pública, pelo respeito à lei e à ordem, ampliando assim o primitivo conceito da areté "militar" para a areté "civil" do cidadão que, vivendo em comunidade, deve resguardar-se das dissenções internas resultantes, em geral, dos períodos de guerra.

Ao lado das composições elegíacas, supõe-se ser Tirteu o autor de alguns cantos guerreiros em rítmo anapéstico, que acompanhavam os soldados no ataque aos inimigos (108); as dúvidas, porém, quanto aos poucos versos conservados e seu desinterêsse para o estudo da elegia, aconselham limitar-nos apenas às Exortações é à Eunomia que constituem os dois grupos das elegias de Tirteu.

As Exortações (109) conservam o espírito das elegias de Calino, igualmente voltada para a virtude guerreira, e como elas destinadas aos jovens que não devem consentir em que seus pais suportem a

\footnotetext{
(106) . - V. Jaeger, op. cit., 87-88.

(107). - Oração, 18, 170.

(108). - Genèricamente eram conhectdos por méle polemisteria, como diz a Suida; e, em particular, por embateria, que indlcava a marcha mllitar de rítmo enérgico e vivo, usual para o ataque. Estes cantos eram aulédicos entre os lacedemônios; e, daf, o mesmo acompanhamento nos cantos de Tirteu. Dêles apenas nos restam seis versos anapésticos, em dialeto dórico culto, citados por Diáo Crisóstomo, atribuidos a Tirteu por Bergk e contestados por Diehl que, além das razóes métricas e dialetals, julga tratar-se de versos do sfeculo II a.C. Neles, diz Croiset: "le triple orgueil de la race, de la caste politique et des traditions milltaires anime le patriotisme du poète"... (op. cit., II, pág. 110).

(109). - São os textos mais completos que nos restam de Tirteu, dos quals se conservaram 114 versos, em três partes distintas, e que devemos ás citaçóes de Licurgo (Contra Isócrates) e de Estobeu.
} 
sós os riscos dos combates. Às virtudes de uma moral heróica conservada da epopéia - Tirteu opõe o opróbrio dos que se desterraram longe da pátria derrotada e a tristeza do exílio; descrevendo, ainda em oposição, a majestade da morte dos que tombaram na primeira linha.

A construção das elegias guerreiras em Tirteu mantem-se no esquema de uma "dialética latente" entre as grandezas e misérias da guerra, de um lado enaltecendo os hoplitas e peltastas no combate corpo a corpo com o inimigo, e de outro descrevendo a triste sorte reservada aos covardes. "Ici, peu ou point de mythes; nul récit, nul retour sur le passé; rien qu'un appel véhément à la vertu, avec des tableaux énergiques du sort réservé soit au brave soit au lâche. C'est le contraste entre la bravoure et la lâcheté qui est le motif essentiel de ces morceaux et qui en détermine la composition. Les deux idées s'opposent l'une à l'autre et chacune à son tour est anlysée en ses parties" (110).

Entretanto, era natural que as exortações guerreiras dirigidas aos soldados conservassem algo do sentimento heróico da epopéia; e, realmente, vemos ainda em Tirteu expressões mantidas da poesia épica anterior.

Porém, pela mesma razão, o estilo destas exortações deveria ser simples, evitando-se as imagens verbais mais comuns às elegias gnômicas que reclamam meditação, e repetindo-se as expressões que mais diretamente alcançam a alma guerreira. Se o apêlo nem sempre encontra no simples contraste o convencimento que a exortação procura, a repetição de um mesmo verso especialmente destinado a despertar, na descrição da luta, o sentimento guerreiro, dará à elegia o resultado que a simples oposição de imagens não alcançara.

Não devemos, pois, sobrestimar nas elegias guerreiras a importância do contraste como se realmente neles existisse uma lógica da demonstração. Seu valor é ainda mais de ordem plástica, como preparação aos versos que constituem pròpriamente a exortação repetida algumas vêzes, e nos quais se encontra, em geral, a imposição do dever heròicamente sentido como a própria ação militar.

Em geral, a oposição, que não é ainda pròpriamente dialética, é menos importante como convencimento lógico do que como resultado plástico de uma arte que se dirige mais aos sentimentos do que à razão. De outro lado, os versos que se repetem não seguem em progressão discursiva, como conclusão de ordem lógica servindo para novo argumento. São apenas bordões que se sucedem, sem maior necessidade, além da memorização de um procedimento militar ou

(110). - A. e M. Croiset, op. cit., II, pág. 113. 
de um dever heróico, e que têm lugar mais na constrıção plástica e musical do que na construção lógica.

Exemplo desta repetição temos nos versos que aparecein exortan. do o guerreiro a "que cerre os lábios e se mantenha rígido ao solo, com as pernas em posição de passo" e que, na verdade, dizem mais respeito à arte militar do que à moral do dever; completando-se, outra vez, a postura, com mais êstes versos: "cobrindo com a parte baixa do seu largo escudo as coxas e as pernas, com a de cima, o peito e os ombros, e com a mão direita brandindo a lança pesada" ...

De outro lado, o contraste de imagens algumas vêzes leva à conclusão. Depois de descrever a nobreza dos que caem lutando na vanguarda, à qual se opõe a miséria do cativeiro, conclui-se no poema: "Assim, se tão pequena é a idéia para um errante, tão pequena a honra, o respeito e a piedade, lutemos com vontade por esta terra, morrendo para nossos filhos, sem nunca poupar as nossas vidas".

Outras vêzes o convencimento é dado por uma inteira inversão da ordem natural de valores, servindo a construção plástica, que ultrapassa, em sua densidade dramática, o heroismo da epopéia, como princípio para a vida guerreira. E' o que vemos nestes versos: "ten to a vida por inimiga e os negros Espíritos da Morte tão caros como os raios do sol". Entretanto, sòmente a leitura mais completa dos poemas que nos restam poderá dar uma idéia mais próxima da construção plástica que se sobrepõe, em seus resultados poéticos, ao esquema de oposições que não é ainda pròpriamente dialético.

A exortação de Tirteu (111), pela análise da miséria que recai sôbre o covarde errante, em cativeiro, "cobrindo de vergonha a sua estirpe e de mentira a sua beleza", enquanto "nada há de mais belo do que a morte do herói, na vanguarda", realmente constitui uma novidade para a moral heróica na qual a morte sempre temida, era

(111). - "Pois, é uma bela coisa para um homem, cair e morrer, lutando na vanguarda, pela sua terra natal; enouanto deixar a sua cidade e seus ricos campos e viver como mendigo, é de tôdas as coisas a mais miserável; errando com sua mãe estimada e pal idoso, com suas pequenas crianças e com a mulher com que se casou. Poís oảioso será êle entre tocios aquêles para os quais vier em cativeiro, na indigência e repugnante miséria; cobrindo de vergonha a sua estirpe e de mentira a sua beleza, seguido pela desgraça e deshonra. Assim, se tão pe đuena é a idéia para um errante, tão pequena a honra, o respeito e a piedade, lutemos com vontade por esta terra, morrendo para nossos filhos, sem nunza poupar as nossas vidas. Permanecei pois, oh! jovens, ombro a cmbro, e Iutai; năo vos deis à torpe fuga nem ao mêdo, mas tornai o coraça em vosso peito, ambos grande e intrépido, sem nunca recuar quando lu. tando contra o inimigo nem, vos evadindo, deixeis os velhos - de quem os joelhos fá não são mais ligeiros - cairem sôbre a terra. Pơts, na verdade, sería torpe o mais velho tombar na vanguarda tendo atrás o mais jovem; com sua cabeça branca e barba grisalha expirando sôbre a poeira a sua alma valente, com o ventre sangrando em suas mãos - quadro 
apenas aceita como o Destino, sem que se tivesse dela a certeza de uma glória, como se vê nestas palavras de Aquiles a Ulisses: "Divino filho de Laerte, engenhoso Ulisses! Devo dizer lealmente, sem rodeios, o que tenho em meu espírito e que certamente acontecerá" ... "vê-se bem que não há gratidão alguma por aquêle que encarniçadamente se bate, sem tréguas, contra os inimigos. Combatendo com ardor ou permanecendo na retaguarda, igual é o proveito. A mesma honra espera o covarde e o herói, e a morte a ambos igualmente trata" (112).

Ainda em outro de seus poemas (113) vemos Tirteu invocar, à semelhança da epopéia, " a nobre estirpe do invencível Heracles, como lá se aludia à ascendência divina. Se a proteção dos deuses sempre pareceu indispensável ao herói homérico, também em Tirteu, mais veladamente, porém, ela ainda é lembrada: "pois não se

horrendo de se ver, e carregado de tanto mal aos que o contemplam, com suas carnes descobertas; para o jovem, tojavia, tudo é decente, desde que tem a nobre beleza da amável juventude, sempre agradável de ver, para os homens e desejável pelas mulheres pelo tempo em que viver, e igualmente belo se caido na vanguarda. Assim, que cada um cerre os lábios com os dentes e se mantenha rígldo ao solo, com as pernas em posição de passo" (Fragmento 10, conservado por Licurgo, Contra Isócrates).

(112). - - Il., IX, 308 e ss.

(113). - "Vós sois da extirpe do invencível Heracles, e portanto sois de ânimo forte; pois - de vós - não se distanciou ainda a cabeça de Zeus. Não temais a multidão dos homens, nem vacileis, mas que cada um levante retamente o seu escudo para a vanguarda, tendo a vida por inimiga e os negros Espíritos da Morte tão caros como os raios do sol. Pois vós conheceis as proezas destruidoras do lamentável Ares e bem aprendestes as vicissitudes da dolorosa guerra; experimentastes, uma e outra, a retirada e a perseguiçäo do inimigo, jovens, e de uma e outra tivestes mais do que era a capacidade de cada um. Dentre aquêles que, permanecendo ombro a ombro, com determinação seguem para a vanguarda, são menos os mortos; e, para o futuro, êles salvam o povo; enquanto que para aquêles que se entregam ao mêdo, todo o seu valor é perdido, e ninguém poderá dizer, em palavras, todos os males que acontecem para um homem se uma vez caiu êle em deshonra. Pols é grato, nas terrívels lutas da guerra, traspassar o dlafragma de um homem que foge, e desgraçado é o morto que jás na terra com a lança ponteaguda nas costas. Assim, que cada um cerre os lábios e se mantenha rígido ao solo, com as pernas em posição de passo, cobrindo, com parte do seu largo escudo as coxas e as pernas, em baixo e, em cima, o peito e os ombros, e com a mão direita brandindo a lança pesada; e que, sôbre sua cabeça se agite a terrível cimeira do elmo; que aprenda a lutar praticando valentes proezas e năo segurando o escudo nas mãos, além dos projéteis. Nâo só, mas que cad homezn se aproxtme do inimigo e que com sua longa lança ou alnda com sua espada golpeie e tome o adversário, com êle tendo pé junto a pé, escudo contra escudo, elmo ao lado de elmo, e cimeira junto a cimeira, contra êle lutando peito a peito, com espaca ou longa lança na mão. E vós, também, vós de armas leves, inclinadas com uma das mãos debaixo do escudo, lançando grandes pedras e contra êles atirando seus suaves dardos, tomais lugar ao lado dos homens de armamento mais pezado". (Fragmento 11, conservado por Estobeu). 
distanciou ainda de vós a cabeça de Zeus". A irrevogabilidade do Destino, entendido como a morte, alcança em Tirteu uma expressão diversa: de um lado, são conhecidas "as proesas destruidoras do lamentável Ares", e de outro, "para o jovem tudo é decente" - em oposição ao "quadro horrendo de se ver o mais velho tombar na vanguarda tendo atrás o mais jovem" - desde que tem a nobre beleza da amável juventude, sempre agradável de ver, pelo tempo em que viver, e igualmente belo se caido na vanguarda".

A grandiosidade da morte do guerreiro na vanguarda constitui nas elegias de Tirteu o motivo de convencimento mais repetido e de maior densidade. Ele está associado, como seria natural, à própria grandiosidade com que se idealiza o guerreiro, e que bem se revela nestes versos: "Não! Eu não poderia evocar a lembrança, nem colocar em meus cantos alguém por proezas, na raça dos guerreiros, ainda que possuisse a grandeza e a fôrça dos Ciclopes e mais velocidade tivesse que o Bóreas Trácio, e mesmo que em seu porte mais graça houvesse que em Titão, e de riquezas maiores que Midas ou Ciniras, ainda que sendo maior rei que Pélope, filho de Pântalo, e tivesse a voz persuasiva de Adrasto, se tôdas as suas glórias o salvassem de não ter coragem na guerra; pois ninguém pode ser um bom guerreiro sem haver suportado o sangrento morticínio, junto a êle estando e para adiante prosseguindo a bater o inimigo" (114).

O elogio ao valor - título dado a êstes versos de Tirteu prossegue com a alusão "desta mais nobre virtude" que é "o prêmio mais puro e nobre que os jovens devem conquistar no mundo".

$\mathrm{E}$ a razão se encontra nos versos seguintes, nos quais a virtude do guerreiro é vista como o "bem comum", "para a cidade e para todo o seu povo".

A parte, porém, o sentido coletivo do dever - que constitui uma novidade com relação à epopéia, na qual o dever se legitimava como determinação do Destino no apelo à ação heroica - êle é, ainda em Tirteu, tal como em Homero, um seńtimento (115) e não um valor imposto. E, é na circunstância de ser a coragem ainda uma paixão (116) que está a razão da elegia como exortação guerreira, destinada a despertar o sentimento do dever, com os recursos das construções plásticas da poesia e das melodias de ação (117).

A glória na posteridade - que sabemos constituir um dos elementos da ação heroica na epopéia - permanece ainda como um

(114). - Fragmento 12, in Estobeu, Antologia.

(115). - V. Il., XI, II; XIV, 151; XVI, 529; XV, 232, 594; Od. XXIV, 318.

(116) . - Aristóteles, Etica a Nicómaco, III, 8, 1116 b, 25.

(117). - Aristóteles, Politica, VIII, 5. 
dos motivos da elegia guerreira, com o mesmo sentido da imortalidade homérica. Depois de descrever a ação do guerreiro - com maior grandiosidade do que nos poemas anteriores - Tirteu se volta para os que tombam na vanguarda, dizendo; "com maior razão aquâle que cai na vanguarda, e que perde a sua estimada vida para a glória de sua cidade e de seus concidadãos" ... "será deplorado igualmente por jovens e velhos, e lamentado com doloroso pezar por tôda a sua cidade. Notável entre todos são seu túmulo e seus filhos, seus netos e a progênie que é por vir; nem jamais parecerão o seu nome e a sua glória, e embora coberto pela terra, viverá na imortalidade" ... "Esta é a glória que todo homem deveria neste dia aspirar".

Ao lado das exortações guerreiras, encontramos em Tirteu o apêlo à boa ordem e à lei, como era necessário para Esparta que ainda vivia as discordias da guerra; e, é especialmente nestes versos da Eunomia que vemos alusões mais longas às construções míticas do passado.

Elas existem, por certo, também na elegia guerreira (118); porém, sem constituirem uma invocação ao passado com propósito de exortação.

$\mathrm{Na}$ Eunomia, entretanto, êsse propósito é claro; e, é nas construções míticas relembradas aos espartanos que se encontra a razão para um direito divino de govêrno, pelos anciães e reis, como vemos escrito por Plutarco (119); "Estando a multidão reunida, ninguém mais além dos senadores e reis tinha direito a propor as questões para deliberação; e, uma vez propostas, o povo era senhor para decidir. Mais tarde, porém, como o povo alterasse e violentasse os decretos com supressões e adições, os reis Polidoro e Teopompo, inseriram na Rhetra o seguinte: "Se o povo alterar os decretos, os senadores e reis se retirem", isto é, não os ratifiquem, e os rejeitem, dissolvendo a assembléia do povo, por alterar e falsificar as decisões, em contrário à equidade. A seguir, persuadiam os cidadãos a aceitar a inovação como ordenamento divino, ao qual aludem êstes versos de Tirteu: "Eles ouviram a voz de Febo e de Pito, trouxeram os oráculos de Deus e palavras de um certo desígnio; pois desta maneira respondeu, de seu rico santuário, Apolo, de cabelos louros, que longe atira com seu argênteo arco: $O$ conselho pertencerá juntamente aos Reis pelos deuses honrados, que tem nos seus cuidados a agradável cidade de

\footnotetext{
(118). - "Vols sois da extirpe do invencível Heracles", ... "pols nfo se distanclou ainda a cabeça de Zeus", .... "Negros Espíritos da morte" (Keres): "proezas destruidoras do lamentável Ares", ... "quando o cruel Ares o pôs por terra" .....

(119) . - Vida de Licurgo, 6.
} 
Esparta, e aos anciães - senadores; depois dêles virão os comuns, que dêles aprovam as justas leis (120) sem dar à cidade qualquer conselho perverso; e, assim terá o povo vitória e poder; pois isto é o que para a sua cidade declarou Febo, a respeito destas questões (121).

Ả importância da inovação mítica como recurso para a exortação da Eunomia, se associa mais a invocação de um passado, como um sentimento histórico de valor religioso que, por essa razão, deve ser resguardado dos inimigos.

Assim é que na Eunomia encontramos mais os seguintes versos: "Pois, o próprio Zeus, nascido de Cronos, e esposo de Hera, com linda corôa, é que deu esta cidade aos descendentese de Heracles, com os quais viemos dos Erineos soprados pelos ventos para habitar a grande ilha de Pélope".

"Dans ce petit nombre de vers, on peut encore saisir quelques uns des traits essentiels des poèmes - diz Croiset. D'abord, la noble inspiration du poète, qui, pour réconcilier les âmes, les arrache aux mesquines préocupations du présent (122) et les force de s'unir dan: la vénération religieuse du passé: c'est Zeus, c'est Appolon qui ont fait Sparte; des rois dignes de leur rôle l'ont conservé; il faut respecter l'oeuvre des dieux et des ancêtres" (123).

$$
\text { III. - A elegia erótica. }
$$

Uma alusão de Horácio (124) e o uso que entre os epicureus tiveram as elegias de Mimnermo, consagraram a errônea indicação de sua poesia como e exortação ao prazer, nela se procurando, algumas vêzes, a antecipação da pregação hedonística.

Entretanto, seria inteiramente errôneo, lembra Jaeger, ver na sua poesia uma expressão decadente de volúpia (125) .

Ela assinala, por certo, um novo período no lirismo grego; porém, mais do que a aparente exortação ao prazer, é ainda o pessimismo herdado da epopéia e repetido nos Trabalhos e Dias que constitui suạ principal razão.

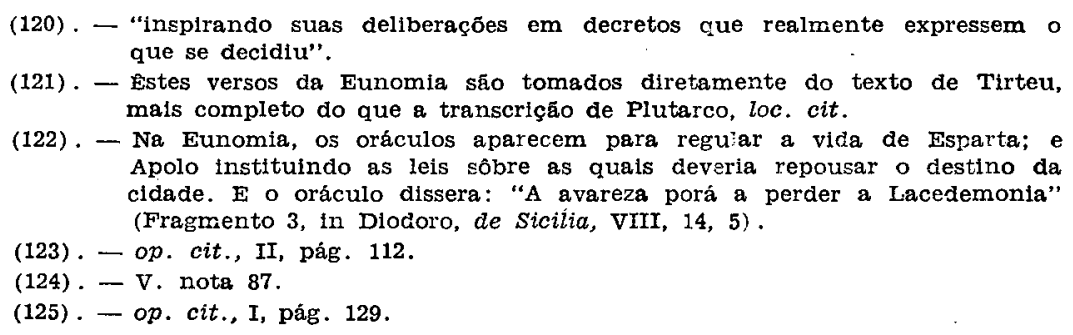


Se nela se lembram os prazeres do amor, com a especial invocação da loura Afrodite, é porque sem êles de nada valeria a vida, sendo melhor a morte. Sem constituir, pois, uma poesia sensual como se poderia supor - é ela, a nosso ver, a primeira expressão de um existencialismo grego, nascido mais da angústia e do pessimismo ante os males sem remédio cantados por Hesíodo, de que de um real sentimento de prazer pela vida.

Assim, se de um lado contrasta com a exortação guerreira, na qual Tirteu incitava a "ter a vida por inimiga, e aos negros Espíritos da Morte tão caros como os raios do sol", de outro, dela repete o sentimento de desvalor da vida, apenas procurando nos prazeres do leito um novo heroismo que a exortação guerreira sòmente conhecera nos campos de batalha (126) .

Mais importante, pois, do que a solução aparente encontrada pela elegia erótica, é o problema moral nela implícito - de desvalor da vida - que é uma das expressões do pessimismo com que o espírito grego, em geral, aceita a existência, a partir dos males sem remédio enviados por Zeus.

Dêsse sentimento, não estão ausentes os motivos estéticos que levam a elegia erótica a ver na velhice o maior dos males: "Zeus deu a Titão a dádiva do mal de uma velhice eterna, que é ainda pior do que a triste morte" (127). Terminada a juventude, diz Mimnermo, muito mais que o viver vale o estar morto, - pois ela destrói inteiramente a beleza da juventude; inimiga, ela nos densonra. Este sentimento domina de tal sorte a poesia de Mimnermo que o pudor estético nela constitui um motivo de maior relêvo do que os prazeres de Hebe. Na realidade, êstes prazeres, têm mais o valor de constraste com os males sem conta que nos perseguem do que de solução nara a miséria da vida, na qual nem ao menos podemos saber, dos deuses, o bem e o mal. A incapacidade de a consciência moral poder assim distinguir e escolher o bem, conduz à solução existencial dada por Mimnermo na exortação ao prazer.

Esta interpretação, que ousamos sugerir em lugar da tradicional indicação de um lirismo erótico - que apenas vê nas elegias de Mimnermo as cantigas de amor, tão celebradas pelo hedonismo (128) - tem a vantagem, a nosso ver, de aproximar as suas com-

(126). - "Enquanto Hesiodo procurou no trabalho o remédio para suas tendências pessimistas" ... "Mimnermo dirigiu-se para um hedonismo sem valor" (V. J. C. Optstelten, Sophocles and Greek pessimism, pág. 171).

(127) . - Fragmento IV.

(128). - A partir, especialmente, dos elegíacos de Alexandria, ünicamente voltados para a paixăo e que "le reconnaissent pour maitre et l'invoquent. Ceux de Rome en font autant, et c'est ainsi encore que la postérité a l'habitude de le considerer" (Croiset, op. cit., II, pág. 118). 
posiçōes das tradições literárias herdadas de Hesíodo, e continuadas, no próprio lirismo, especialmente com Teognis .

De outro lado, é certo, também, que Mimnermo não esteve inteiramente alheio à elegia guerreira, que o precedeu, nem ao emprêgo das tradições mitológicas na poesia lírica, de maneira a se dizer de uma poesia sòmente pessoal, na qual apenas se revela o que de "mais íntimo existia na alma, o amor e a melancolia".

Apesar de não pertencer à tradição dórica (129) Mimnermo teria composto também elegias marciais, entretantó mais de caráter histórico e mitológico, relativas à guerra de Esmirna contra a Lídia (130); $\mathrm{e}$, provàvelmente pertenceram a êste poema os versos em que põe em relêvo o valor de um guerreiro, segundo a tradição que ouvira de seus pais (131), assim como alguns outros versos esparsos - que Estrabão, ao citar, diz haver tomado de uma das obras de Mimnermo intitulada Nanó - os quais aludem às origens de Esmirna e de Colofão. São êles, porém, versos que apenas tem algum interêsse pelo relêvo neles dado à mitologia, à semelhança de como Tirteu, na Eunomia, invocara a orígem divina de Esparta.

A divisão de sua obra em dois livros, tendo um dêles por título Nanó - que era o nome de uma executante do canto aulédico que se julga ter sido amada por Mimnermo - e outro o de Catalepta, remonta a Calímaco; porém, é bem provável tratar-se de títulos dados posteriormente, pelo menos quanto ao primeiro dêles, em razão das numerosas vêzes em que nas suas elegias Mimnermo alude ao nome de Nanó.

Entretanto, ao contrário do que se poderia supor, Nanó é precisamente o livro das elegias históricas e mitológicas - "animadas de vibração épica" - nas quais na primeira parte, ou em várias de-

(129). - "Filho de Ligirtiades, de Colofão, ou Esmirna, ou Astipaleia, autor de Elegia. Floreceu na 37a. Olimpiada (632-629) e assim precede aos Sete Sábios, ainda que algumas autoridades o julguem ser dêles contemporâneo. Era também chamado Ligiastades, porque era doce e claro (ligys), isto é, musical"'. (Suidas, Lexicon).

(130) . - "Mimnermo, no Prelúdio dos seus versos Elegíacos, escreve sôbre a guerra entre os ermirneus contra Giges e os lidios, dizendo que as antigas musas eram nascidas de Urano, e as mais jovens nascidas de Zeus" (Pausanjas, Descriçâo da Grécia).

(131). - "Não era sua a débil fôrça e a pobre nobreza de coraçáo, dizem meus pais que o viram desbaratar as serradas fileiras de cavalaria lídia na planície de Hermo, derrotando-as com a lança; nem jamais haveria Palas Atenas de encontrar razäo para censurar o causticante poder de um coração tal como o dêle, quando, corria para a vanguarda, desdenhando os contundentes profétels dos inimigos, no mass pesado da guerra sangrenta. Pois ninguem jamais cumpria melhor a obra de um combate cruel funto de seus inimigos, quando êle seguia com um raio de Sol" (Fragmento 14, in Estobeu, Antologia). 
las, "Mimnermo, a quem os longos sofrimentos levaram a encontrar a doce música e os ternos suspiros do pentâmetro, ardia por Nanó" (132) consagrando-lhe os versos.

As dúvidas que se tem levantado quanto a êste pormenor não teriam interêsse para a compreensão da obra de Mimnermo, na qual, como já salientamos, não se deve procurar a poesia íntima que à primeira vista pareceria existir, pois "ce n'est plus comme le poète d'une passion particulière que Mimnerme nous apparaît; c'est comme le chantre de l'amour en général, du plaisir et de la jeunesse" (134) ou, mais pròpriamente, a nosso ver, como o primeiro anunciador de uma solução existencial para a vida de males que nos perseguem, e para a odiosa velhice que leva a escolher a morte.

$\mathrm{O}$ acento dado à alegria de ser jovem, com os prazeres do leito sem os quais nada seria a vida, não deve, a nosso ver, sobrepor-se ao real conteúdo das elegias que nela apenas procuram o proveito que nos resta contra o horror à velhice e contra a certeza de que ao homem não é dado, nem ao menos, saber do bem e do mal.

Em verdade, entre as expressões de melancolia - que constituem, sem dúvida, o motivo real das elegias de Mimnermo - e a exortação ao prazer, não haveria escôlha, pois que o prazer apenas serve, à construção poética, para agravar o desespero de quem, "não importa quão belo tenha sido, não será nem mais honrado nem amado, nem pelos seus próprios filhos, quando passada a juventude" (135). A oposição se limita a um permanente contraste, sem qualquer progressão que nos leve a entrever uma libertação do melancólico desespêro. E' ainda a consciência mớal agitada pelo pessimismo herdado da própria mitologia da epopéia, e desenvolvida, em têrmos mais humanos e não menos pessimistas, por Hesíodo.

De outro lado, é preciso lembrar que êste desespero não renascia, originàriamente, em Mimnermo, encontrando-se, igualmente na poesia jâmbica dêle contemporânea, ou mesmo anterior, como se su-

\footnotetext{
(132) . - De acôrdo com um dístico do proêmio dos de Calímaco, descoberto no papiro de Oxyhrinchus 2.079. Diz o dístico: "e é também verdade que das suas obras, não a grande, intitulada com o nome de mulher, mas a outra, a coleção de poesias menores, demonstra que Mimnermo é um poeta delicado". V. Horácio, Epist. II, 2, 100-101.

(133). - - o que dêle diz seu compatriota Hermesianax, quatro séculos mais tarde (Ateneu, XIII, 597, F.). Entretanto, em nenhum dos fragmentos que nos restam de Mimnermo, vemos qualquer alusáo a Nanó; e a autoridade de Hermesianax, por quem, apenas, sabemos do amor de Mimnermo, é duvidosa.

(134) . - A. e M. Croiset, op. cit., II, pág. 120.

(135) . - Fragmento 3, in Estobeu, Antologia.
} 
põe ser a de Arquíloquo e de Simônides de Amorgos (136), apesar da maneira diversa por que era tratado.

Entretanto, a aproximação entre Mimnermo e os compositores jâmbicos, não deve autorizar, como quer Jaeger (137), ver na elegia erótica o mesmo espírito de uma mensagem comum, nos têrmos em que se lê: "Tal como Simonides de Amorgos, Mimnermo de Colofão escreve para proclamar a alegria da vida. Esta mensagem, que em Arquíloquo é sòmente um produto derivado de poderosos instintos naturais e expressos no humor do momento, constitui, em seus dois sucessores, o último segrêdo da vida. Ela se torna uma cruzada. um ideal de vida ao qual querem converter tôda a h:manidade".

A coincidência na invocação aos prazeres de Hebe é apenas parcial, e com um espírito muito diverso; e, o "novo passo na poesia helênica" não está, a nosso ver, "na maneira livre pela gual o poeta escreve de seus prazeres íntimos e que teria agido poderosamente sôbre a cultura", mas na maneira por que o pessimismo, antes alicerçado em construções mitológicas, como a da jarra de Pandora em punição ao crime de Prometeu, encontrará nas próprias vicissitudes da existência uma razão próxima e humana da qual se alimentará nas idades posteriores à moral religiosa. Este entendimento, que não seria despropositado ainda que interpretando a poesia jâmbica, daria ao hedonismo grego um sentido moral menos vulgar - que não necessitaria da poesia e de doutrinas para agir sôbre a cultura - sen do mais a expressão da melancolia com que o espírito grego entrevề a morte, a velhice, as doenças e as desgraças (138) do que a simples pregação do prazer sensual que, não constituindo o "último segrêdo da vida", não reclamava a "conversão de tôda a humanidade" por meio de uma cruzada poética.

Nem ao menos se poderia procurar, como exortação nas elegias de Mimnermo, o sentido de uma reivindicação de direito, como sugere Jaeger a propósito da poesia elegíaca e jâmbica posterior a $\mathrm{Ar}$ quíloquo; "Quando êles pregam o hedonismo, não é uma esc.̂̉ha acidental para o indivíduo que se anuncia; mas um princípio universal que é o "direito" de todo o indivíduo de gozar a sua própria vida" (139). De qualquer modo, dessa atitude, que Jaeger procura ver nos poetas hedonistas - como se no trânsito do período heróico para o humano comum, guardasse a poesia um propósito educacional

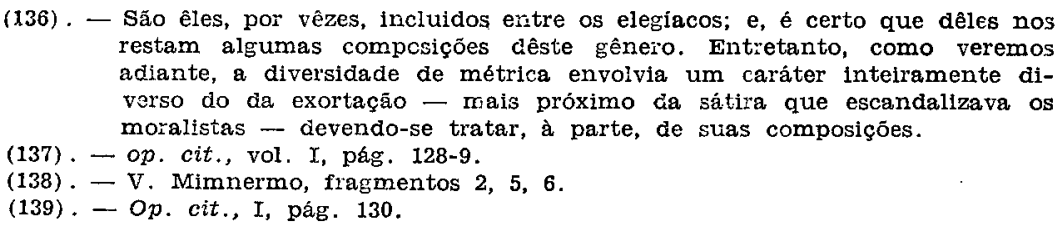
restam algumas compcsiçóes cêste gêneio. Entzetanto, como veremos adiante, a diversidade de métrica envolvia um caráter inteiramente diverso do da exortação - mais próximo da sátira que escancalizava os moralistas - devendo-se tratar, à parte, de suas composiçōes.

(137). - op. cit., vol. X, pág. 128-9.

(138). - V. Mimnermo, fragmentos 2, 5, 6.

(139). - Op. cit., I, pág. 130. 
agora voltado para os valores próprios de uma existência que passa breve "como a luz do sol nascente que se espalha ao longe" - não estaria ausente "uma lógica aplicada à Natureza, que não hesitou em arrostar o problema da vida humana, invadindo e inspirando a poesia que era ainda o meio para a expressão das idéias éticas, levndo-a a discutir os problemas morais" (140).

Entretanto, já salientamos, a propósito da exortação elegíaca, as limitações do que nela se procura entrever como dialética latente; e, com menos razão, a nosso ver, se poderia procurar nas elegias de Mimnermo uma "lógica aplicada à Natureza", a ponto de julgar-se a exortação ao prazer como a reivindicação de un direito.

Em verdade, o contraste, sempre repetido, entre os prazares da juventude e os males da velhice, não vai além de uma construção poética de proporções plásticas e de resultados que procuram o convencimento, mais do sentir do que da razão; e, se algama lógica é possível nessa construção, ela será mais a lógica sem razão da existência, que nos leva à melancolia e aos desespêro, do que a lógica que, aplicada à Natureza, levou os milesianos às primeiras doutrinas cosmológicas .

Sem concordar, pois, com os grandes propósitos que Jaeger encontra na elegia erótica, a ponto de nela ver uma escola hedonística que assinala um dos mais importantes períodos da história do espírito grego, sempre em luta, entre a vontade individual dirigida para o prazer e a virtude, voltada para o bem, o que nos parece realmente nela existir é apenas a voz que, nas palavras do próprio Jaeger, "lastima, cada vez com maior tristeza, o império do destino e as dádivas de Zeus" que devem ser aceitas tal como nos vîm, lamentando sempre com maior desespêro a brevidade da vida"... (141) sem que, nesse lamentos se encontre, igualmente, a transitoriedade dos prazeres como entende Jaeger - que aparece na exortação da elegia erótic apenas para por em relêvo, os males que nos esperam.

$\mathrm{E}$, por essa razão, é que quanto mais "alguém se entrega à exigências da natureza, e mais intensamente se dá aos seus prazeres, maior será a melancolia da resignação que haverá de seguir-se" ... "quando todos os perigos que traiçoeiramente alcançam a vida humana crescem como gigantes que o ameaçam em todo sôpro ensaiado; e mesmo que dêles procure escapar, nos prazeres do momento, ainda os encontrará envenenados pelo sofrimento que tortura o mundo".

(140). - Ibidem.

(141). - Ibidem, pág. 129. V., a propósito da irrevogabili la je do Destino, pelo qual tudo o que é cestinacio ao homem, em vica, vem de zeus e dos deuces, e assim tem que ser aceito, Arquíloque, frajto. 8, 58, 68; Semonides, fragto. 1, 1ff.; Solon, fragto. 1, 64; Peognis, v. 134, 142, 157. 
Esta passagem de Jaeger (142) que concorda mais de perto com os versos de Mimnermo e com espírito pessimista da moral helênica anterior a Sócrates, em verdade o aproxima mais dos estoicos do que dos hedonistas; a menos que, como nos parece acontecer, se considere tanto o hedonismo como o estoicismo expressões do mesmo sentimento de melancolia e de angústia que inspira a moral helênica, de um modo geral, vendo-se, no primeiro, a expressão espontânea imediatamente encontrada na ordem existencial, e nos estoicos uma meditação crítica que conduz à solução diversa, de ordem racional.

De outro lado, é preciso ter sempre presente na poesia lírica anterior ao racionalismo lógico que só alcança sua primeira expressão entre os eleatas, a importância dos elementos estéticos que seguem ao lado das idéias morais; e, mais do que uma eventual lógica aplicada a natureza, é na sensibilidade estética que a elegia de Mimnermo encontra o recurso principal da exortação. "The Greek sentiment of hatred for old age - diz Symonds - is well expressed in one epithet which Mimnernus employ - amorphon, formless. The Greeks detested the ugliness and loss of grace which declining years bring with them, almost more than weakened powers or the approach of death" ... His feeling for the charm of youth was intense; he expressed it in language that reminds us of the fervency of Sappho - "Down my flesh the sweat runs in rivers, and I tremble when I see the flower of my equals in age gladsome and beautiful". This tender and regretful strain is repeated by Mimnermus with a monotonous, almost pathetic persistency, as if one thought of inevitable age oppressed him like a nightmare day and night. His delight in the goodliness of youth and manhood is so acute, and his enjoyment of existence so exquisite that he shrinks with loathing from the doom imposed on all things mortal to decline and wither"... "In his verse we trace the prostrate tone of the Oriental, combined with Greek delicacy of intellect and artistic expression" (143).

$E^{\prime}$ certo que, mais tarde, o horror à velhice perderá a importância que teve para os gregos, como vemos, especialmente no discurso de Céfalo, com que Platão inicia o livro I do República; entretanto, é mister lembrar que a êsse tempo a moral já se construira sôbre conceitos racionais, tendo em vista o Bem soberano para o qual se deslocara a noção de virtude, interpretando-se a consciência moral em têrmos de um conhecimento das idéias racionais em oposição ao

(142). - Ibidem, V. Mimnermo, fragto. 2-6. A propósito dos males que em silêncio alcançam o homem, v. o sentido de Elpis, (Elpis cativa e o problema do mal, loc. cit.) e, mals, $T$. e D. 90-105.

(143) . - Op. cit., I, págs. 228-9. 
mundo sensível. Mesmo assim, porém, há algo que sobrevive naquele discurso, lembrando o sentimento de desvalor da vida que prossegue para a velhice, e os prazeres que nela já não existem: ... "os prazeres da juventude e do amor desapareceram; era aquêle um bom tempo, mas, agora, já passado, a vida não é mais vida" ... porém, "a verdade, é que estas lamentações devem ser atribuidas não à velhice mas ao caráter dos homens e seus temperamentos, pois aquêle que é de natureza calma e tranquila não sentiria tanto o pêso da idade; mas para aquêle de disposição contrária, tanto a juventude como a idade constituem igualmente uma carga" (144) .

De qualquer modo, porém, não devemos procurar nas elegias de Mimnermo motivos isolados, de sorte a dar a uns e outros o relêvo que nos conduziria ou a uma interpretação apenas hedonística, que em geral tem prevalecido, ou a uma interpretação pessimista e melancólica partindo apenas do sentimento de temor pela odiosa velhice.

Como em qualquer outra construção artística, há nas elegias de Mimnermo uma unidade de inspiração que não se parte com o contraste; e, se o motivo dessa inspiração é menos visível do que nas elegias guerreiras é porque na elegia erótica estão presentes as contradições da existência, experimentadas como realidades vividas que nem sempre poderiam conter-se nos conceitos estritos dos valores, nem em imagens que alcançam o poder de convencimento pela variedade de seu colorido verbal.

E' uma poesia existencialista - o quanto se poderá dizer na qual a melancólica exortação ao prazer apenas revela a impossibilidade de conhecer dos deuses o bem e o mal, ou de dêles evitar as duras penas que nos são enviadas, e, dentre elas, a velhice.

Aliás, a alusão aos prazeres sensuais, em linguagem tão poética e inspirada na mitologia, não poderia constituir uma expressão de sensualismo, como entenderam os elegíacos de Alexandria. Além de rara, é ela posta em têrmos de contraste com a idéia central dos versos em que aparece, e que se iniciam por uma nota melancólica presente em todo o seu poema: "que seria a vida, e que prazer nela haveria" (145). E, em lugar de aspirar pela eternidade do prazer como seria próprio de um hedonista sensual - aspira desde logo a

(144). - V. 329 a - d.

(145) . - "Que seria a vida, e que prazer nela haveria, sem a loura Afrodite. Possa eu morrer quando fá não me valerem o amor secreto, as dádivas amávels e o leito, que são as belas flores da juventude, tão queridas pelo homem como pela mulher. E quando a dolorosa Idade vier, tornando ao homem louco, sem elas, ou, com elas, depravado, os cuidados pelas suas doenças cançarão de mais e mais o seu coração; não terá êle mais alegria em ver a luz do sol; para as crlanças será odioso e para as mulheres, desprezivel, tão dolorosa os deuses tornaram a velhice" (Frag. 1, in Estobeu, Antologia). 
morte quando passada a juventude. A nostalgia com que nos descreve a dolorosa idade que torna o homem desprezível para as mulheres, é acompanhada de um sentimento claro de pudor, que nã.) poderia existir para o hedonismo. Assim, os prazeres da juventude, na velhice, são depravação do homem de coração cançado pelas doenças, e já sem alegria "em ver a luz do sol", "tão dolorosa os deuses tornaram a velhice". Nem é a velhice, sòmente aquela desprezada pelas mulheres; pois, ainda para as crianças ela será odiosa"!

Em outros de seus versos (146) a angústia parece sobrepor-se inteiramente a qualquer idéia de prazer, erguendo-se ao lado do homem os Espíritos da Morte, um dêles trazendo a dolorosa velhice - que é o têrmo da vida - e o outro, a própria morte. Passada a maturidade, "melhor do que viver é o estar morto"; não, porém, porque já não sobrevivem os prazeres, mas porque "muitas são as dores que então nascem no coração": O sentimento de um pecado original - à maneira de Hesíodo - ou a simples consciência do mal, inspira êstes versos que terminam pelo convencimento de que "não há ninguém no mundo a quem Zeus não tenha dado numerosas penas". Entretanto, a nós "não nos deram os deuses a conhecer nem o bem nem o mal".

A impossibilidađe desta distinção que constitui, sem dúvida, - primeiro problema da consciência moral, diminui a responsabilidade pela virtude e pelo dever. Ela consentirá - e, neste ponto parece estar o problema central da moral de Mimnermo - na atitude de um existencialismo epicurista mais teórico do que sensual; talvez, mais poético do que prático: "L'épicurisme pratique n'était pas, chez Mimnerme l'exubérance irréfléchie d'une nature sensuelle. Il y entrait de la réflexion, et partant de la tristesse. Il avait dit avant Horace: Carpe diem ..., vive memor quam sis oevi brevis; et il avait dit, sans doute, dans un sentiment analogue de mélancolie douce et résignée" (147).

\footnotetext{
(146). - "Porém nós, como as fôlhas que vêm na florida Primavera e que briIham, por tăo pouco, aos raios do sol, como elas nós desfrutamos, apenas por uma estação, que é pequena, as flôres da juventude; não nos tendo dado os deuses a conhecer - prever - nem o bem nem o mal; pois aqui ao nosso lado se erguem os Espíritos da Morte, um cêles com o fim, que é a dolorosa Velhice, e o outro com o que é a Morte; e a colheita da juventude é passageira, tão rápida quanto o sol que se levanta estende ao longe a sua luz. E quando a maturidade houver passado, entáo melhor do que viver é o estar morto; pois muitas são as dores que nascem no coraçåo; umas vêzes nossa casa é assolada e as dolorosas proezas c'a Miséria nos vêm; ou, outros, que não tiveram descendentes, vão para a Morte os desejando mais que tudo; e, mais, será êle tomado por dcença que destroém o seu coração - pois não há ninguém no mundo a quem Zeus nāo tenha dado numerosas penas" (ibidem).

(147) . - A. e M. Croiset, op. cit., I, pág. 121.
} 
Dentre os golpes com que a velhice nos alcança, maiores «ão aquêles que "causam mal à vista e à razão (148) destruindo o corpo que nela perde a beleza da juventude. Ainda que por tradição con siderado um poeta do prazer, "il a touché le fond de la sensation, et il a trouvé ce fond médiocre. C'est son originalité de l'avoir dît pour la première fois en des vers que la Grèce n'a plus oubliés. (149).

(148). - "Inesperado e abundante suor se derrama de meu corpo, e eu tremo ao contemplar o amável e alegre tempo primaveril de minha geração, pois eu queria que êle durasse para sempre, mas a precioza juventude é ce duraçấo tấo pequena quanto um sonho, e a triste e horrenda Velhice pende sôbre nossas cabeças, Velhice igualmente odiosa e rumilhante, que torna o homem amorfo, causando-lhe com seu golpe, mal à vista e à razão. (Fragto. 5, in Estobeu, Antologia) .

(149) . - A. e M. Croiset, ibidem. 